Ethiopian Journal of Environmental Studies \& Management 8(1): 13 - 27, 2015.

ISSN:1998-0507

doi: http://dx.doi.org/10.4314/ejesm.v8i1.2

Submitted: June 27, 2014

Accepted: January 09, 2015

\title{
SPATIAL PATTERN AND ORGANISATIONAL STRUCTURE OF INTRA-URBAN TRIPS IN OGUN STATE, NIGERIA
}

SOLANKE, M.O.

Department Of Geography and Regional Planning, Olabisi Onabanjo University

P.M.B. 2002, Ago-Iwoye, Nigeria. Email: solankeolayiwola@yahoo.com

\begin{abstract}
This study examines spatial pattern and organization of intra-urban trips in Ogun State, Nigeria. Data on intra-urban travels for various purposes were collected from 2,100 households in 14 selected urban centres through questionnaire survey. The percentage distribution technique was used to establish the aggregate proportion of intra-urban trips to different land uses on weekdays and weekends' basis. The variation in intra-urban trips for different purposes was examined using analysis of variance while interrelationships between the trips were examined through correlation technique. Intra-urban trips are generated for work, school, religious, recreation, shopping, social and others [errands, pleasure visit, etc].Work and school trips dominate with 34 and 35\% of aggregate trips respectively. Religious trips follow with 14\% while other trip types feature in lower proportion: shopping [7\%], social [4.12\%], recreation [3\%] and others [2\%]. Trips for different purposes are positively correlated $(r \geq 0.9, P \leq 0.01)$ although significant variation exists in their number for different purposes across the cities. ( $F=4.142, P \leq 0.01)$. About $90 \%$ and $95 \%$ of work and school trips respectively in each urban centre are generated on week days .About $66 \%$ of recreation trips, $84 \%$ of religious trips $96 \%$ of social trips and over $50 \%$ of trips categorized as others are generated on weekends in different urban centres. Shopping trips feature remarkably across weekdays and weekends. There is high positive relationship between weekday and weekend trips ( $r=0.99, P \leq 0.01)$. The study recommends the need to closely monitor the relative location of work and educational land uses in relation to residences in an attempt to manage intra-urban commuting on weekdays. The detail characteristics of recreation, religious, and social trips are recommended for effective management of intraurban trips on weekends. Interdependent nature of intra-urban trips calls for holistic approach to general intra-urban trips planning.
\end{abstract}

Key Words: Intra-urban trips, urban trips organization, trip generation, trip planning, weekend trips, weekday trips.

\section{Introduction}

Urban centres all over the world are characterized by a set of activities, which actually account for concentration of people in them. These include those arising from manufacturing, trading and finance, transportation and tertiary activities. All these combine to generate the spatial 
configuration of the city because their requirements are sometimes functionally differentiated and also spatially segregated. The spatial segregation of urban land use types creates spatial imbalance and this necessitates spatial interaction for functional interrelationships (Aderamo 2004, Solanke 2005). Trip generation thus constitutes an inevitable aspect of urban life. This is so, because in many countries, living accommodation and places of other activities such as work, school, recreation etc. are no longer in close proximity. People now travel prodigious distance either within or between cities to fulfill their needs for necessities and or luxuries (Adeniji 1982, Sunmaila and Adetunji 2004). The urge or desire to satisfy felt needs arising from the separation of activities no doubt constitute a major factor of urban movement.

Human movements within city provide vital clues to understanding of human spatial behavior especially in developing world where measures of telecommunication are not likely to prove of much value given the low level of technology and generally poor economic condition (Gbadamosi, 2004)

The significance of using person trips to characterize the urban system cannot be over-emphasized. The urban trips, consequent upon urban travels represent the fundamental measures of the interdependence of the components of the city (Ayeni 1974, Solanke 2005). Trips can be made to relate to city structure as in the case of the journey to work and residential location or even to economic and spatial growth through a linking of the factors of growth to the changes in employment and consequent changes in interaction (Axhausen and Garling 1992). To this extent, an examination of urban travel behavior constitutes a worthwhile academic exercise and, according to Chapin (1974) and Dimitriou (1995) should follow among others the capacity of the various landuses to generate and attract trips.

Intra-city travel behavior, therefore lays emphasis not only on the interrelationships that exist between landuse categories but also on the relationship between activities and people on the space. Thus, urban travel behavior is viewed both as the prerequisite and the consequence of the spatial separation of activities.

The symbiotic relationship between transport and land uses therefore is onereason geographers are interested in urban transportation. Therefore, the study of urban trip generation is a response to the ever-growing need of man for movement within city. One can hardly hope to understand the spatial structure of the city or to grasp how it is changing without an appreciable knowledge of movement patterns. An urban travel is an issue of daily concern. It is a dynamic catalyst to a nation's social and economic development and as such deserves a continuous attention and understanding. Thus, in this study, attempt is made to examine the structural pattern of intra-city trips in Ogun state of Nigeria. Specifically, the study examines spatial pattern and classification of intraurban trips. In other words, the study focuses on spatial analysis and categorization (between weekdays and weekends) of intra-urban trips. These are considered paramount issues to put in perspective the notion of efficiency in the spatial organization of urban activities.

\section{Study Area \\ Geographical Location}

Ogun State is located in South western Nigeria within latitudes $6^{\circ} \mathrm{N}$ and $8^{\circ} \mathrm{N}$ and longitudes $3^{\circ} \mathrm{E}$ and $5^{\circ} \mathrm{E}$. The state is 
bounded on the west by the Republic of Benin and on the east by Ondo State. To the north is Oyo state while Lagos State and the Atlantic Ocean are to the south (figure 1). The state covers about 16,762 square kilometer which is approximately 1.81 percent of Nigeria's land mass of about 923,768 square kilometers (Akanni; 2000).

\section{Geology and Relief}

The geology of the state comprises the sedimentary and basement complex rocks. According to Akanni (2000), about $1,200 \mathrm{~km}^{2}$ of the state is of sedimentary formation while about $400 \mathrm{~km}^{2}$ is of basement complex rocks of pre-Cambrian formation.

There are two main relief regions: first, the creeks and lagoons forming a small section in the south eastern part of the state, the altitude of which ranges from 0 to 40 meters above the sea level. Second, the undulating coastal plain and the low land with the elevation increasing northwards from about 30 to 250 meters above sea level. The plain is broken by sand stonecresta especially towards the western part of the state. There are pockets of rock outcrops dotting the landscape especially around state capital (Abeokuta). The whole state is drained by flowing coastal rivers such as Ogun, Yewa, and Shasha from Oyo state through the thickly vegetated western part of the state. Numerous small rivers and streams are at the south eastern parts flowing perennially through the swampy terrain.

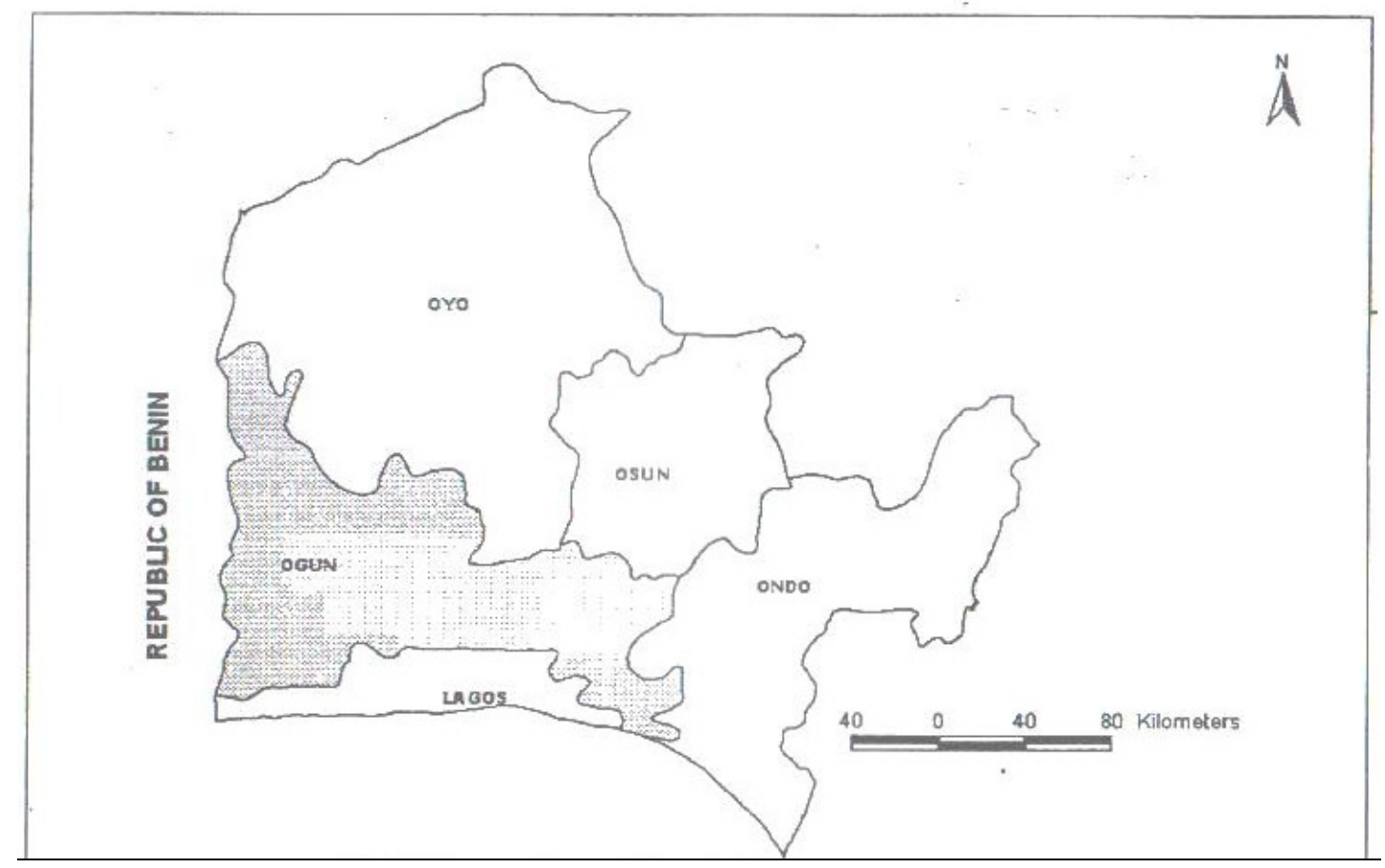

Figure 1: Ogun State and its neighbours

\section{Climate and Vegetation}

The state is within the tropical humid climatic zone of Nigeria which generally characterized, by high rainfall and high relative humidity. This is attributable to the prevalence of moisture laden tropical 
Maritime air mass over the state for about nine months in a year. The mean relative humidity varies from $66.2 \%$ in January to $88.4 \%$ in July (Akanni, 2000).

The rainfall shows a double maxima distribution reaching the peak during the months of June and September. The average monthly rainfall for the state ranges between $7.1 \mathrm{~mm}$ in the month of January to $208.27 \mathrm{~mm}$ in the month of June. The mean annual temperature is $26^{\circ} \mathrm{C}$; although with some variations over time. The mean diurnal minimum temperature varies from $21.8^{0}$ cin December to $24.34^{\circ} \mathrm{C}$ in April while the mean diurnal maximum temperature varies from $33.92^{\circ} \mathrm{C}$ to $37.1^{\circ} \mathrm{C}$ at the onset of the wet season (March and April) (Akanni, 2000).

On the basis of climatic features, the state is characterized by two distinct weather seasons: the wet and dry. The wet season marked by lower mean temperature, higher total rainfall and higher relative humidity is usually experienced between the months of February and October. However, little dry season is sometimes experienced in August, a phenomenon characterized by drastic reduction in the frequency and intensity of rainfall and referred to as August break. The dry season sets in by November and persists till the end of January. It is usually accomplished by harmattan cold, brought by the prevailing north-west winds.

In terms of vegetation, the state can be divided into three distinctive zones. Where the state shares a boundary with the Atlantic Ocean, the vegetation is of a swampy type with mangroves and other edaphic trees. There is also rainforest vegetation in some section of the state while the state capital (Abeokuta) and some areas are characterized by derived forest vegetation, having been altered by human activities.

\section{Socio-Economic Activities}

In the pre-colonial era, the economy of the state, like those of most other traditional Nigeria towns was characterized by farming, craft production, trade and town administration (Oyesiku, 1990, Ademiluyi 1996).

The establishment of colonial rules in the state brought new forms of economic activities which are characteristics of western economy, and there have also been modifications to the traditional system of production. Thus, several identifiable modern economic activities including insurance house, modern and traditional markets, petrol stations, motor companies, commercial enterprises, light and heavy industrial organizations are now found in different urban centres in varying degrees.

Some settlements, especially the capital (Abeokuta) benefited immensely from their early contact with the European population (the missionaries) who helped in the development of such areas by establishing mission houses, schools, churches, dispensaries and hospitals.

Agriculture the mainstay of the economy provides the major single occupation for the people of the state especially those in the rural areas. Arable crops like maize, yam, cassava, rice, cocoyam, groundnut, melon, banana plantain, oranges, pineapple, sugar-cane and kola nuts are produced in the state. The major export crops produced are cocoa, coffee, rubber and palm kernel. In the Riverine areas, people engage in extensive fish farming. Lumbering activities also thrive because the state is endowed with appreciable forest resources. This perhaps accounts for the high number of sawmills in the state. 
Another major economic activity in the state is extensive trading and light commercial merchandising. The people are engage in buying and selling of all types of goods ranging from local household utensils in food, beverage and manufactured goods.

The industrial sector constitutes another economic activity. Among the major industrial types in the state are: food, beverages and tobacco, textile, weaving apparel and products, fabricated metal products, wood and wood products, chemical products, pulp, paper products, printing and publishing, non-metallic minerals, motor vehicles and miscellaneous assemblies, domestic/industrial plastic and rubber products and electrical and electronics (Odugbemi, 1993). The potentials of the state for industrial development are as a result of her natural, agricultural and forestry resources and proximity to Lagos and Ibadan (Odugbemi, 1993, Odugbemi and Solanke, 1997).

People in the state also engaged in paid employment of the local, state and federal government agencies, others engage in business activities which are dominated by distributive trade, personal services, transportation, finance and insurance services.

To complement the socio-economic development of the state are: education, health, telecommunication, postal and insurance institutions and other socioeconomic services and infrastructures that exist in many towns. For instance, the state has about 1424 public primary schools, 474 public secondary schools, 7 government technical colleges, 1,120 registered private nursery and primary schools, 257 registered private secondary schools, 2 colleges of education, 4 polytechnics, 3 public universities and 8 private universities.
Also there are 88 hospitals/clinics (public and private), 210 maternity centres, 202 dispensaries, 16 comprehensive/primary health centres, 4 dental centres and 1university teaching hospital. Notable tourist attractions in the state are Olumo Rock at Abeokuta, BirikisuSungbo Shrine at Oke-Eri, EbuteOni Beach, Oroma Shrine and Celestial city at Imeko

\section{Methods}

This study is on urban trip generation. The source of data is questionnaire survey for urban residents on household basis. Following the works of Ogunjumo (1986), Oyesiku(1990)Dimitriou (1995),Solanke (2005)and Osoba (2011), household is a well-known key decision-making unit for the general movement pattern and constitutes the major point of origin of urban travel.

An urban centre is defined in this study as the settlement with a total population of 20,000 people or more in conformity with United Nations and the definition of urban centre in the Nigeria National population census of 1963, 1991, and 2006. On the basis of this definition, 22 settlements in the state qualify as urban centers. 14 of these in different categories (such as large, medium and small) in terms of population sizes were randomly selected. They are: Abeokuta (the state capital) Ijebu-ode, Sagamu, Ilaro, Ago-iwoye, Ota, Ijebu-igbo, Ayetoro, Ifo, Iperu, Ado-odo, Idi-Iroko, Owode-Yewa, and Alagbado.

A household survey was conducted in each of these urban centres to generate data on urban travel. Each urban centre was divided into residential quarters along the demarcation of the town into residential neighborhoods by town planning authorities. In each of the neighborhoods, 
random selection of streets and systematic sampling of the housing unit were made. The household sample size for each urban centre was based on the estimates for each urban centre. There were about 425,789 households in all the selected urban centres, out of which 2,385 were sampled in proportion to the number of households in each urban centre (Table 1). 2,100 fully completed copies of the questionnaire were used in this study. The questionnaire dealt with intra- urban travels and activity pattern of urban residents.

All the possible trips were divided into seven purposes namely work, schooling, recreation and others` (errand, pleasure, job seekers) following the works of Oyesiku (1990, 1995) Solanke (2005) Hanson and Schwab (1995). Urban residents were requested to construct their intra-urban trips within the past one week to the time of survey. The immediate past week to the date of survey was chosen in order to collect the information from people while they were still fresh in their memory, thus, enhancing the accuracy of the information.

The percentage distribution method was used to establish the proportion of the aggregate trips to different land uses and different period of the week (weekdays and weekends). This is supported by bar charts for necessary illustration. Analysis of Variance technique was used to examine the significance of variation in number of trips generated for different purposes; while the nature and strength of relationships between the trip purposes on one hand as well as between weekday and weekend trips on the other hand were established through Pearson product moment correlation technique.

Table 1: Urban centres in Ogun state, their population estimates, estimated number of households and sample sizes.

\begin{tabular}{lllll}
\hline S/N & Urban centres & $\begin{array}{l}\text { Estimated } \\
\text { population }\end{array}$ & $\begin{array}{l}\text { Estimated } \\
\text { of households }\end{array}$ & $\begin{array}{l}\text { Household } \\
\text { sample size }\end{array}$ \\
\hline 1. & Abeokuta & 707,277 & 141,455 & 792 \\
2. & Ijebu-ode & 248,103 & 49,621 & 278 \\
3. & Sagamu & 255,680 & 51,136 & 286 \\
4. & Ilaro & 78,046 & 15,609 & 87 \\
5. & Ago-Iwoye & 59,409 & 11,882 & 67 \\
6. & Ota & 207,194 & 41,439 & 232 \\
7. & Ijebu-Igbo & 130,182 & 26,036 & 146 \\
8. & Ayetoro & 60,475 & 12,095 & 68 \\
9. & Ifo & 105,165 & 21,033 & 118 \\
10. & Iperu & 46,386 & 9,277 & 52 \\
11. & Ado-odo & 46,103 & 9,221 & 52 \\
12. & Idi-Iroko & 34,906 & 6,981 & 39 \\
13. & Owode & 78,902 & 15,780 & 88 \\
14. & Alagbado & 71,122 & 14,224 & 80 \\
Total & & $2,128,950$ & 425,789 & 2,385 \\
\hline
\end{tabular}

\section{Results and Discussions}

\section{Patterns of trips generation}

Intra-urban trips generated by purpose in the state are presented in table 2 and figure 2 . The total number of trips made in the entire region during the survey period was 88790. Of these, trips to work accounted for $34 \%$ while those to schools 
constituted 35\%. Thus, journeys to work places and schools (obligatory trips) dominate trips generated in the area, accounting for more than two-thirds of all trips. These two were followed by journeys to religious centres (14\%), shopping centres (7\%) and social activities (4.12\%). Recreation accounted for about 3\%while 'others` including those made by job seekers, those sent on errands and visits to relatives and friends took the remaining $2 \%$.With $\mathrm{F}=4.142$ and $\mathrm{P} \leq 0.01$ (Table 3 ), there is significant variation in the number of trips generated for different purposes in the study area.

The dominant position of journey to school and work is perhaps explained by the fact that schooling and office work constitute the major activities in these urban centres. These landuse types (work and school) must therefore; form the main explanatory variables (especially their relative locations to residences) in any attempt to structure intra- urban commuting in the state.

The trips component in individual urban centres in the region reveals a similar pattern to that of the regional structure. In each of the urban centres, school and work trips accounted for the highest proportion of trips generated; the proportion varied from one urban centre to another.

The pattern of work trips in urban centres suggest that the small and medium sized urban centres like Ota, Iperu, Ilaro ,Ifo, Idi-Iroko and Owode have a higher proportion of work trips than the largesized urban centres like Abeokuta, Ijebuode and Sagamu. This finding is an apparent reflection of settlement characteristic feature, particularly, in the developing world; younger people tend to migrate from rural and semi-urban areas to major urban centres for one opportunity or the other, leaving behind the elderly ones who make work trips more than any other trip types (Solanke 2006).

Another observation from table 2 especially on the proportion of work and school trips in different urban centres is that large -sized urban centres like Abeokuta, Ijebu-ode and Sagamu have higher proportion of school trips than work trip while the medium sized urban centres like Ilaro, Owode,Alagbado and Iperu have higher proportion of work trips than school trips. This suggests the presence of more students in large-sized urban centres than medium and small- sized cities in the region. The concentration of educational institutions in the large-size centres is responsible for this finding.

Recreation trip is generally low for all the urban centres in which Ado-odo with about $6 \%$ has the highest, followed by AgoIwoye and Ijebu-Igbo (5\% each) and others with less than $5 \%$. The generally low proportion of recreational trips in the state may be explained by the fact that tourism as a way of life and foreign exchange earner has not really received the required attention in Nigeria and invariably in the state. The proportion of trips generated for shopping also varies among the urban centres. Iperu with about $13 \%$ is the highest, followed by Abeokuta (9\%) AgoIwoye and Alagbado (8\% each) Ijebu-ode, Sagamu, Ota and Ijebu-Igbo (7\% each) and Ayetoro with about $2 \%$.

The highest proportion of shopping activities in most urban centres can be explained by the nature of commercial activities in the state which are dominated by the traditional market and frontage retail shops in residential areas, which constitute the focal points for everyday buying and selling by the urban residents. 
Religious trip is the third dominant trip type in Ogun state after work and school. Ijebu-Igbo and Ado-odo with about 23\% each are the highest, followed by Idi-Iroko and Owode (17\% each). The fairly high proportion of religious trips in the state may be explained by the proliferation of churches and other religious centres in the state particularly in the recent time.

Social trips like other trip types vary among the urban centres. Ago-iwoye, with about $8 \%$ had the highest, followed by Ijebu-Igbo and Ilaro (6\% each),Ijebu-ode, Iperu and Ado-Odo(5\% each) and Idi-Iroko and Alagbado (2\% each). The high proportion of social trips in such urban centres as Ago-Iwoye, Ijebu-Igbo and Ilaro may be explained by presence of large numbers of students in them.
The proportion of trip types categorized as 'others' in this study is low and varies among urban centres. Alagbado has the highest proportion with $8 \%$ followed by Iperu with $6 \%$, Abeokuta and Ijebu-ode (3\% each) and other urban centres such as Ilaro, Ago-Iwoye and Ota have less than $2 \%$ each, while Ijebu-Igbo, Ayetoro, Ifo, Ado-odo and Idi-Iroko have less than $1 \%$ each. The correlation matrix of intra-urban trip purposes (Table 4) shows a highly significant positive relationship between them. This shows that a decision on trip generation for one purpose has influence on trip generation for other purposes. Trip generation in the study area can therefore be described as multi-collinear in nature. 
Table 2: Intra-city trips Generated by purpose in Ogun state.

Trip purpose

\begin{tabular}{|c|c|c|c|c|c|c|c|c|c|c|c|c|c|c|c|c|}
\hline \multirow[b]{2}{*}{ City } & \multicolumn{2}{|l|}{ Work } & \multicolumn{2}{|l|}{ School } & \multicolumn{2}{|c|}{ Recreation } & \multicolumn{2}{|c|}{ Shopping } & \multicolumn{2}{|c|}{ Religious } & \multicolumn{2}{|l|}{ Social } & \multicolumn{2}{|c|}{ Others } & \multicolumn{2}{|l|}{ Total } \\
\hline & No & $\%$ & No & $\%$ & No & $\%$ & No & $\%$ & No & $\%$ & No & $\%$ & No & $\%$ & No & $\%$ \\
\hline Abeokuta & 11,446 & 33.79 & 11,737 & 34.65 & 945 & 2.79 & 2,812 & 8.30 & 4,519 & 13.34 & 1,352 & 3.99 & 996 & 2.94 & 33,874 & 100 \\
\hline Ijebu-ode & 3,449 & 32.94 & 3,631 & 34.68 & 361 & 3.45 & 745 & 7.11 & 1,528 & 14.59 & 486 & 4.64 & 271 & 2.59 & 10,471 & 100 \\
\hline Sagamu & 3,676 & 32.55 & 4,363 & 38.64 & 438 & 3.88 & 815 & 7.22 & 1,475 & 13.06 & 321 & 2.84 & 204 & 1.81 & 11,292 & 100 \\
\hline Ilaro & 1,044 & 38.38 & 869 & 31.96 & 72 & 2.65 & 151 & 5.54 & 395 & 14.51 & 151 & 5.54 & 39 & 1.42 & 2,720 & 100 \\
\hline Ago-Iwoye & 821 & 34.94 & 672 & 28.6 & 106 & 4.53 & 197 & 8.37 & 338 & 14.37 & 184 & 7.81 & 31 & 1.32 & 2,350 & 100 \\
\hline Ota & 3,081 & 36.57 & 3,055 & 36.26 & 131 & 1.56 & 576 & 6.84 & 1,091 & 12.95 & 397 & 4.71 & 94 & 1.11 & 8,425 & 100 \\
\hline Ijebu-Igbo & 1,480 & 28.34 & 1,550 & 29.67 & 245 & 4.69 & 361 & 6.92 & 1,219 & 23.34 & 339 & 6.48 & 29 & 0.56 & 5,223 & 100 \\
\hline Ayetoro & 733 & 36.72 & 795 & 39.81 & 28 & 1.38 & 34 & 1.71 & 334 & 16.73 & 68 & 3.41 & 05 & 0.24 & 1,996 & 100 \\
\hline Ifo & 1,277 & 37.30 & 1,362 & 39.77 & 47 & 1.38 & 166 & 4.84 & 458 & 13.38 & 108 & 3.14 & 07 & 0.19 & 3,424 & 100 \\
\hline Iperu & 628 & 45.05 & 315 & 22.59 & 28 & 2.69 & 181 & 12.94 & 83 & 5.98 & 63 & 4.52 & 87 & 6.23 & 1,395 & 100 \\
\hline Ado-Odo & 356 & 30.74 & 354 & 30.59 & 65 & 5.59 & 55 & 4.71 & 264 & 22.79 & 63 & 5.44 & 02 & 0.14 & 1158 & 100 \\
\hline Idi-Iroko & 397 & 37.14 & 418 & 39.12 & 11 & 1.06 & 34 & 3.18 & 184 & 17.24 & 21 & 1.99 & 03 & 0.27 & 1068 & 100 \\
\hline Owode & 948 & 37.33 & 934 & 36.77 & 29 & 1.14 & 145 & 5.69 & 427 & 16.80 & 58 & 2.27 & 00 & 00 & 25400 & 100 \\
\hline Alagbado & 931 & 32.61 & 846 & 29.65 & 113 & 3.96 & 221 & 7.75 & 461 & 16.16 & 54 & 1.90 & 228 & 7.97 & 2854 & 100 \\
\hline Regional & 30,269 & 34.09 & 30,926 & 34.83 & 2628 & 2.96 & 6544 & 7.37 & 12,777 & 14.39 & 3658 & 4.12 & 1989 & 2.24 & 88790 & 100 \\
\hline
\end{tabular}

Table 3: Analysis of Variance table of intra-urban trips in Ogun State

\begin{tabular}{|l|l|l|l|l|}
\hline & Sum of squares & Degree of freedom & Mean Square \\
\cline { 2 - 5 } Between Groups & 69729698.43 & 6 & 11621616.40 & F \\
Within Groups & 255354971.6 & 91 & 2806098.589 \\
Total & 325084670.0 & 97 & & 4.142 \\
\hline
\end{tabular}

Table 4: Correlation Matrix of Intra - Urban Trip Purposes

\begin{tabular}{|c|c|c|c|c|c|c|c|}
\hline & Work & School & Recreation & Shopping & Religious & Social & Others \\
\hline Work & - & $.998 * *$ & $.961 * *$ & $.996 * *$ & $.987 * *$ & $.979 * *$ & $.957 * *$ \\
\hline School & $.998 * *$ & - & $.968 * *$ & $.992 * *$ & $.987 * *$ & $.972 * *$ & $.947 * *$ \\
\hline Recreation & $.961 * *$ & $.968 * *$ & - & $.969 * *$ & $.978 * *$ & $.953 * *$ & $.933^{* *}$ \\
\hline Shopping & $.996 * *$ & $.992 * *$ & $.969 * *$ & - & $.987 * *$ & $.979 * *$ & $.970 * *$ \\
\hline Religious & $.987 * *$ & $.987 * *$ & $.978 * *$ & $.987 * *$ & - & $.986 * *$ & $.942 * *$ \\
\hline Social & $.979 * *$ & $.972 * *$ & $.953 * *$ & $.979 * *$ & $.986^{* *}$ & - & $.928 * *$ \\
\hline Others & $.957 * *$ & $.947 * *$ & $.933 * *$ & $.970 * *$ & $.942 * *$ & $.928 * *$ & - \\
\hline
\end{tabular}

**Correlation is Significant at 0.01 Level. 


\section{Categorization of Trips}

In this study, trips generated for various purposes were categorized into two: weekdays and weekends trips. Weekdays trips comprise of those undertaken from Monday to Friday which are the official working days in the most government establishment in Nigeria, while weekends' trips comprise of those undertaken on Saturdays and Sundays when most people especially those in formal sectors are off their official duty posts.

The findings as presented in table 5 and Figure 3 show that over $70 \%$ of aggregate trips in each of the urban centres occurred during weekdays while not more than $28 \%$ of aggregate trips occurred on weekends. This shows that urban activities which necessitate spatial interaction within cities occurred mostly on weekdays.

The correlation analysis on weekday and weekend trips shows a positive and very strong relationship $(r=0.99 \quad \mathrm{p} \leq 0.01)$ (table 5). This shows that the situation of intra-urban obligatory trips on weekdays influence correspondingly the directionary trips on weekends.

Table 5: Organization of Intra-urban trips on Weekdays and Weekends basis

\begin{tabular}{llllll}
\hline \multirow{2}{*}{ Urban Centres } & Total trips & \multicolumn{3}{l}{ Weekdays } & Weekends \\
\cline { 2 - 6 } & No & No (Y) & $\%$ & No (X) & $\%$ \\
\hline Abeokuta & 33874 & 25,683 & 75.82 & 8191 & 24.18 \\
Ijebu - Ode & 10471 & 7823 & 74.71 & 2648 & 25.29 \\
Sagamu & 11292 & 8,500 & 75.27 & 2792 & 24.73 \\
Ilaro & 2720 & 2096 & 77.06 & 624 & 22.94 \\
Ago iwoye & 2350 & 1727 & 73.50 & 623 & 26.50 \\
Ota & 8425 & 6494 & 77.08 & 1931 & 22.92 \\
Ijebu - igbo & 5223 & 3899 & 74.65 & 1324 & 25.35 \\
Ayetoro & 1996 & 1544 & 77.34 & 452 & 22.66 \\
Ifo & 3424 & 2746 & 80.21 & 678 & 19.79 \\
Iperu & 1395 & 1022 & 73.26 & 373 & 26.74 \\
Ado -odo & 1158 & 908 & 78.38 & 250 & 21.62 \\
Idi - iroko & 1068 & 844 & 79.05 & 224 & 20.95 \\
Owode & 2540 & 1991 & 78.40 & 549 & 21.60 \\
Alagbado & 2854 & 2070 & 72.52 & 784 & 27.48 \\
\hline \multicolumn{2}{c}{ ryx $=0.99 \leq 0.01$} & &
\end{tabular}




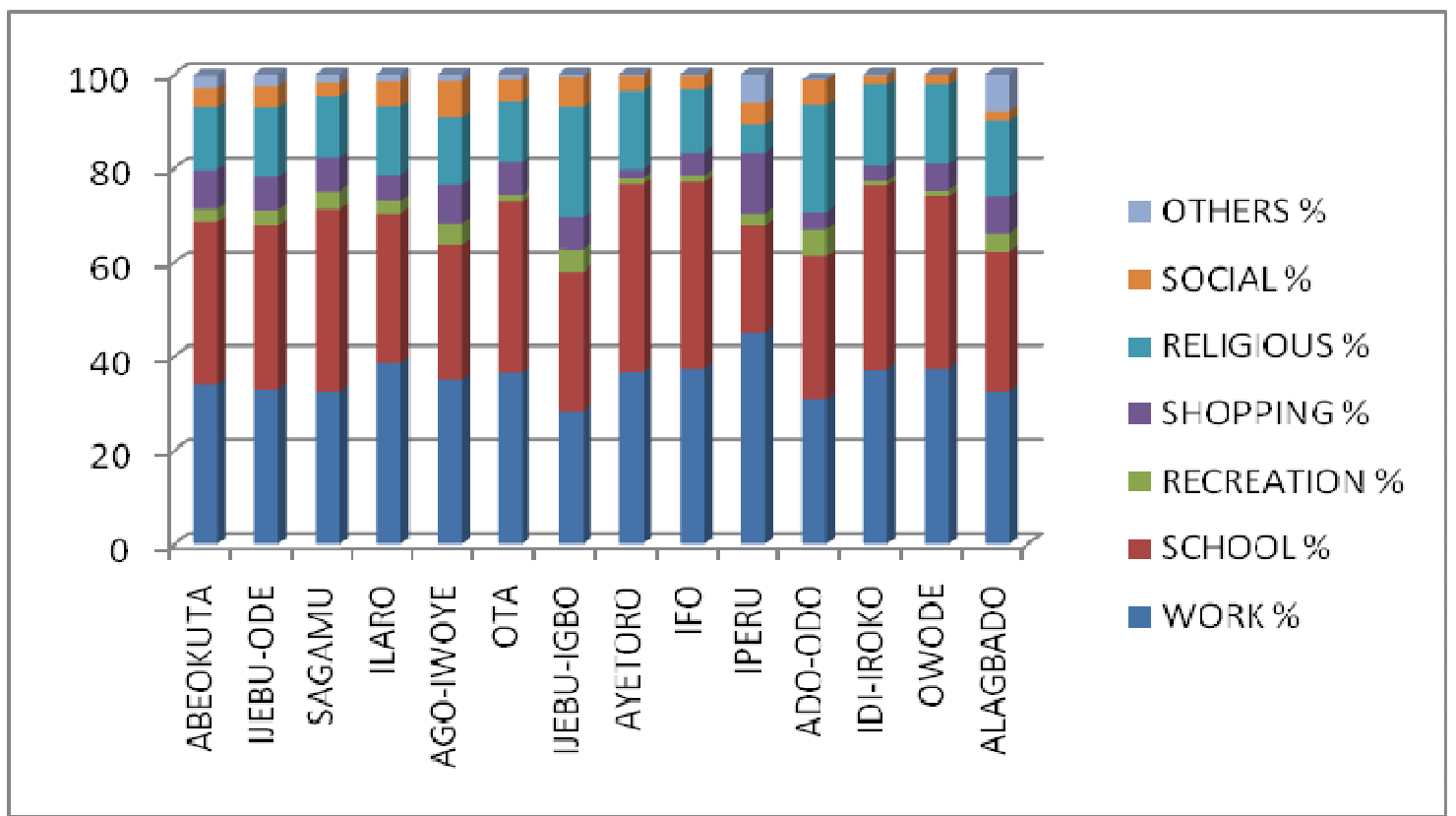

Figure 2: Intra-city trips generated by purpose in Ogun state

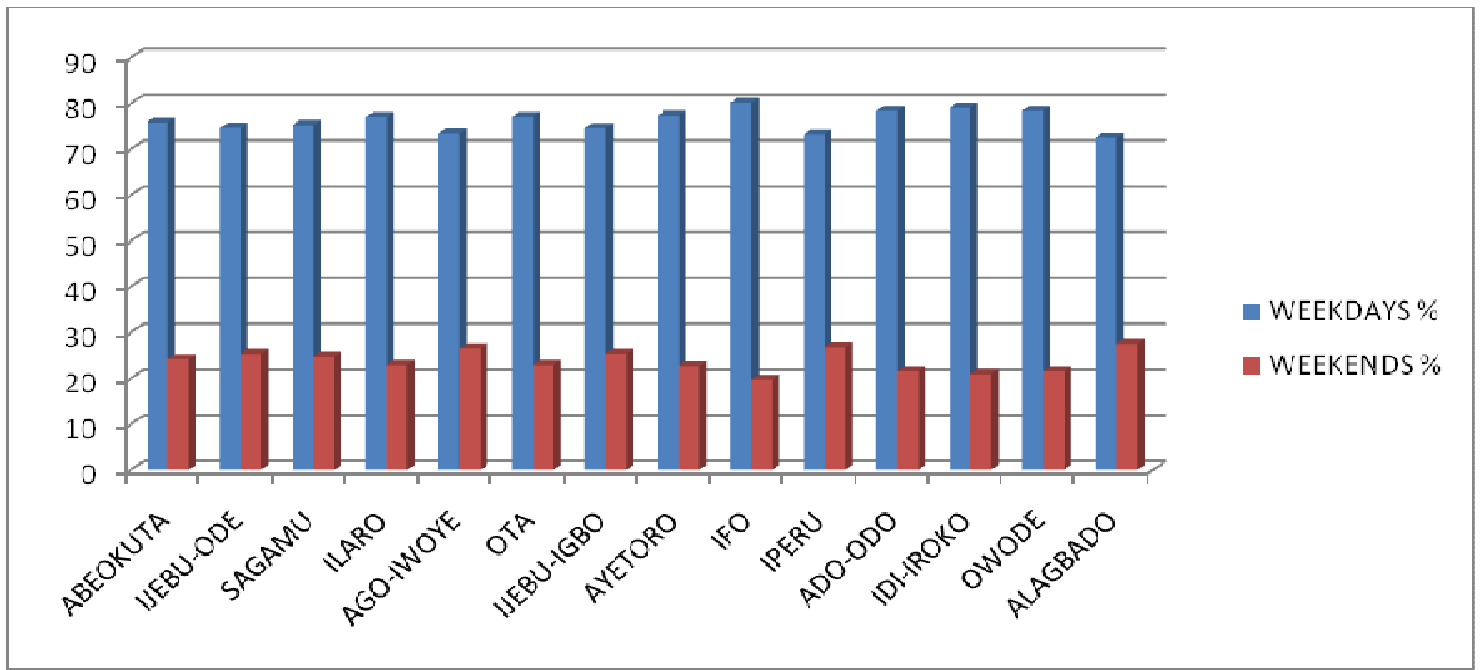

Figure 3: Organization of Intra-City Trips on Weekdays and Weekends Basis

The organization of intra-city trips by purpose (Table 6) shows that obligatory trip purpose (work and school) dominates the weekdays while discretionary trip purposes (recreation, religious, social and 'others') dominate the weekends. Shopping trips on the other hand feature remarkably on both weekdays and weekends. Between $79 \%$ and 94\% of work trips in each urban centre are generated on weekdays. This suggests that most of the respondents in this study are workers in formal sector whose work periods are during weekdays. As expected, not less than $95 \%$ of school trips in each city occur on weekdays.

With exception of Iperu, Ijebu-Igbo and Ado-odo, not less than $66 \%$ of recreational trips in the study area take place on 
weekends. This is a reflection of most peoples' desire to recreate after the hustling and bursting on the weekdays. Between 58 and $84 \%$ of religious trips in each urban centres except Ijebu-Igbo, Iperu and Adoodo take place on weekends and this may be explained by the large number of visits to churches on Sundays.

The substantial proportion of religious trips on weekdays in three urban centres (Ijebu-Igbo, Iperu and Ado-odo) can be explained by large number of practicing Muslims as well as Pentecostal churches who perform most of their religious rites on weekdays.

In a similar manner, with the exception of Iperu, between 29 and $96 \%$ of social trips takes place on weekends. This can be explained by the cultural orientation of the people whereby such functions as burials, wedding and house warming ceremonies occur during the weekends.

As noted earlier, shopping trips in the study area feature conspicuously on both weekends and weekdays. In each urban centre, between 29 and $57 \%$ of shopping trips occur on weekdays, the proportion for weekends is between 42 and $74 \%$.

The indiscriminate manner of occurrence of shopping trips between weekdays and weekends may be explained by frequent visits of most people (especially the low income earners) to markets centres on daily basis, especially for food items. 
Table 6: Organization of Intra-urban trips by purpose

\begin{tabular}{|c|c|c|c|c|c|c|c|c|c|c|c|c|c|c|c|c|}
\hline \multirow{2}{*}{$\begin{array}{l}\text { Urban } \\
\text { Centres }\end{array}$} & \multicolumn{2}{|c|}{ Total Trips\% } & \multicolumn{2}{|c|}{$\%$ Work } & \multicolumn{2}{|c|}{$\%$ School } & \multicolumn{2}{|c|}{$\%$ Recreation } & \multicolumn{2}{|c|}{ \% Shopping } & \multicolumn{2}{|c|}{$\%$ Religious } & \multicolumn{2}{|c|}{$\%$ Social } & \multicolumn{2}{|c|}{$\%$ Others } \\
\hline & $\begin{array}{l}\text { Week } \\
\text { day }\end{array}$ & $\begin{array}{l}\text { Week } \\
\text { end }\end{array}$ & $\begin{array}{l}\text { Week } \\
\text { day }\end{array}$ & $\begin{array}{l}\text { Week } \\
\text { end }\end{array}$ & $\begin{array}{l}\text { Week } \\
\text { day }\end{array}$ & $\begin{array}{l}\text { Week } \\
\text { end }\end{array}$ & $\begin{array}{l}\text { Week } \\
\text { day }\end{array}$ & $\begin{array}{l}\text { Week } \\
\text { end }\end{array}$ & $\begin{array}{l}\text { Week } \\
\text { day }\end{array}$ & $\begin{array}{l}\text { Week } \\
\text { end }\end{array}$ & $\begin{array}{l}\text { Week } \\
\text { day }\end{array}$ & $\begin{array}{l}\text { Week } \\
\text { end }\end{array}$ & $\begin{array}{l}\text { Week } \\
\text { day }\end{array}$ & $\begin{array}{l}\text { Weeke } \\
\text { nd }\end{array}$ & $\begin{array}{l}\text { Weekd } \\
\text { ay }\end{array}$ & $\begin{array}{l}\text { Weeke } \\
\text { nd }\end{array}$ \\
\hline Abeokuta & 75.82 & 24.18 & 91.52 & 8.48 & 99.42 & 0.58 & 23.88 & 76.12 & 57.28 & 42.72 & 22.87 & 77.13 & 25 & 75 & 28.55 & 71.45 \\
\hline Ijebu-Ode & 74.71 & 25.29 & 90.90 & 9.10 & 98.80 & 1.20 & 33.48 & 66.52 & 46.55 & 53.45 & 31.65 & 68.35 & 3.64 & 96.36 & 48.81 & 51.19 \\
\hline Sagamu & 75.27 & 24.73 & 88.85 & 11.15 & 99.55 & 0.45 & 25.28 & 74.72 & 54.53 & 45.47 & 15.66 & 84.34 & 17.50 & 82.50 & 22.83 & 77.17 \\
\hline Ilaro & 77.06 & 22.94 & 94.30 & 5.70 & 97.41 & 2.59 & 33.33 & 66.67 & 25.60 & 74.40 & 41.88 & 58.12 & 21.27 & 78.73 & 12.50 & 87.50 \\
\hline Ago-Iwoye & 73.50 & 26.50 & 91.80 & 8.20 & 98.55 & 1.45 & 26.15 & 73.85 & 48.33 & 51.67 & 38.83 & 61.17 & 21.43 & 78.57 & 36.84 & 63.16 \\
\hline Ijebu-Igbo & 74.65 & 25.35 & 93.7 & 6.30 & 94.59 & 5.41 & 41.44 & 58.56 & 53.13 & 46.87 & 55.42 & 44.58 & 19.05 & 80.95 & 44.45 & 55.55 \\
\hline Ayetoro & 77.34 & 22.66 & 88.50 & 11.50 & 95.90 & 4.10 & 29.41 & 70.59 & 33.33 & 66.67 & 32.04 & 67.96 & 7.14 & 92.86 & 33.33 & 66.67 \\
\hline Ifo & 80.21 & 19.79 & 91.60 & 8.40 & 98.81 & 1.19 & 34.48 & 65.52 & 48.04 & 51.96 & 25.89 & 74.11 & 13.64 & 86.36 & 25 & 75 \\
\hline Iperu & 73.26 & 26.74 & 78.60 & 21.40 & 100 & 0 & 59.09 & 40.91 & 49.05 & 50.96 & 51.02 & 48.98 & 54.05 & 45.95 & 29.41 & 70.59 \\
\hline Ado-Odo & 78.38 & 21.62 & 90.90 & 9.10 & 96.15 & 3.85 & 44.74 & 55.26 & 46.88 & 53.12 & 64.52 & 35.48 & 29.73 & 70.27 & 0 & 100 \\
\hline Idi-Iroko & 79.05 & 20.95 & 89.30 & 10.70 & 100 & 0 & 25 & 75 & 29.17 & 70.83 & 30.77 & 69.23 & 6.67 & 93.33 & 50 & 50 \\
\hline Owode & 78.40 & 21.6 & 89.70 & 10.30 & 97.95 & 2.05 & 22.22 & 77.78 & 38.89 & 61.11 & 36.47 & 63.53 & 13.89 & 86.11 & 0 & 0 \\
\hline
\end{tabular}




\section{Summary and Conclusion}

In this study, the urban trips composition and their organization on weekday and weekend basis are examined. The variations of these among different cities of Ogun state, Nigeria are also considered. Urban trips are generated for work, schools, recreation, shopping, religious, social and 'others' (errand, visitation, pleasure). Obligatory (school and work) trips dominate intra-urban trips in different urban centres with about $70 \%$ of trips generated. While small and medium sized urban centres like Iperu, Ilaro, Ifo, Idi-Iroko and Owode have higher proportion of work trips, the large-sized urban centres like Abeokuta, Ijebu-ode and Sagamu have higher proportion of school trips. In other words, work trips dominate in small and medium sized urban centres, while school trips dominate in the largesized urban centres.

Religious trips emerge the third dominant trip type with about $14.39 \%$ of aggregate trips. Recreation, shopping, social and 'others' trip feature but in low proportion of about $2.9 \%, 7.37 \%, 4.12 \%$ and $2.24 \%$ respectively of aggregate trips. There is significant variation in the trips generated for different purposes in Urban Centres of the state.

On intra-urban trips organization, obligatory trips (work and school) dominate the weekdays. Between 79 and $94 \%$ of work trips in each urban centre are generated on weekday; while not less than $95 \%$ of school trips in each city occur on weekdays. The discretionary trip purpose (recreation, religious, social and those categorize as 'others' (visitation, errand etc.) dominate the weekends with over $60 \%$ of the trip occurring on weekends in most urban centres. Shopping trips feature remarkably on both weekdays and weekends. Between 29 and $57 \%$ of shopping trips occur on weekdays across the urban centres while the proportion for weekends is between 42 and $74 \%$. There is high positive correlation between trips generated for different purposes as well as between the weekday and weekends trips.

The implication of these findings for urban transportation planning cannot be overemphasized. In terms of trip generation within these urban centres, the landuse types to closely monitor are residential, work and educational. This is because trips originating and ending in residential areas and those destined for work places and schools account for a very large share of total daily commuting.

A restructuring of their relative spatial locations to each other is required towards a high improvement on the existing commuting traffic in urban centres of the state and to avoid a chaotic and intractable situation in the future. Furthermore, the large sized urban centres in the state will require adequate provision of transport facilities/services to cope with the large volume of school trips generated in them.

The obligatory trips (work and school) require priority attention on weekdays while discretionary trips should be given more consideration on weekends in an attempt to ensure effective transportation in the urban centres. The interdependent nature of trips generated calls for a holistic approach to planning for intra-urban trips in the state. The spatial pattern and organization of intra-urban trips reveals a discernible structure; this structure should be made to guide the urban transportation in the state both now and in the future.

\section{References}

Ademiluyi, I.A. (1996). An Analysis of Spatiotemporal patterns of inequalities in Ogun 
State, Nigeria, Unpublished Ph.D Thesis, University of Ibadan.

Adeniji, K. (1987). "Public Transportation and Basic Needs satisfaction in Nigeria" Research for Development, 4(1\&2): 292304

Aderamo, A.J. (2004). 'Planning for urban transportation in Nigeria' in Vanduchikolo, I., Ogunsanya, A.A. and Sumaila, A.G. (eds), Perspectives on urban Transportation in Nigeria, NITT, Zaria, Pp.312-331.

Akanni, C.O. (2000). 'Physical Environment' in Onakomaiya, S.O. Odugbemi, O.O. Oyesiku, O.O. and Ademiluyi, I.A. (eds), Ogun state Local and Regional perspectives, Centre for sandwich programmes (cesap) Ogun state university, Ago-Iwoye, Pp.14-25 Ashgate publishing Ltd, Avebury.

Axhausen, K.W and Garling, T. (1992). "Activity based approach to travel analysis: Conceptual frameworks, models and Research problems". Transport Reviews 12(4): 323-341

Ayeni, M.A.O. (1974)."'Predictive modeling of urban spatial structure." The example of Jos, Benue-plateau state; Unpublished Ph.D Thesis, University of Ibadan

Chapin, F.S. (1974). Human activity patterns in the city, John Wiley and sons, New York

Dimitriou, H.T. (1995). A developmental Approach to urban Transport Planning; An Indonesian Illustration

Gbadamosi, K.T. (2.004). 'Telecommuting and urban movement Behaviour' in VanduChikolo, I., Ogunsanya. A.A. and Sumaila,A.G (eds) Perspective on urban Transportation in Nigeria NIIT Zaria , Pp.267-293.

Hanson, S. and Schwab, M. (1995). "Describing Disaggregate Flows; Individual and Household activity patterns" in Hanson, S, (ed) The Geography of Urban Transportation ( $2^{\text {nd }}$ ed) The Guilford press, New York, Pp.166-187.

Odugbemi, O.O. and Solanke, M.O. (1997). 'The geographical Region, Setting,
Structure, and impact of the Ogun state University in Odugbemi, O.O., Balogun, K.A., Adebanjo, A. and Adedoyin, S.F. (ed), Essential of general studies, Centre for Sandwich Programmes (CESAP) Ogun state University, Ago-Iwoye,vol1,pp2041.

Odugbemi, O.O (1993). 'Ogun State' in UdoR.k .and Mamman D (ed) Nigeria; Giant in the Tropics Gabumo press, Lagos Pp 349-362

Ogunjumo, A. (1986). "The pattern of trip generation at Ile-Ife" Journal of Nigerian institute of town planners, VI and VII, 99144.

Osoba, S.B. (2011). "Variation In the ownership of global system for mobile communication (GSM) among socioeconomic group in Lagos, Nigeria" Journal of Logistics and Transport, 3(1): 79-94

Oyesiku, O.O. (1995). “An analysis of demand for inter-city Trip generation attributes of a Developing state in Nigeria". Journal of Transport Studies, 1(1): 17-28.

Oyesiku, O.O. (1990). "Inter-urban travels patterns in Nigeria, A case study of Ogun state". Unpublished Ph.DThesis, University of Benin,Nigeria

Solanke, M.O. (2005). 'Spatial Analysis of Intra-Urban Travel Patterns in Ogun state, Nigeria' Unpublished Ph.D Thesis, University of Ibadan, Ibadan, Nigeria.

Solanke, M.O. (2006). "Analysis of intra-urban Trip generation patterns in Ogun state, Nigeria" Ijagun Journal of Social and Management Sciences, 1(2): 74-82

Solanke, M.O. (2013). 'Urbanization, Intraurban Transportation and the inherent challenges in Ogun state, Nigeria' Journal of logistics and Transport, 5(1): 98-107.

Sumailla, A. and Adetunji, R. (2004). "Future perspectives in urban Transportation" in Vandu-chikolo, Ogunsanya, A.A. and Sumaila, A.G.(eds) Perspectives on urban Transportation in Nigeria, NIIT Zaria Pp.370-381 